\title{
Studies on Biodegradation of 4-Chlorophenol and 4- Nitrophenol by Isolated Pure Cultures
}

\author{
Apurba Dey ${ }^{1}$, Priyanka Sarkar ${ }^{1}$ and Ananya Das ${ }^{2}$
}

\begin{abstract}
Metabolically versatile pure cultures were isolated from textile dye effluent and petrochemical industry which were able to utilize $150 \mathrm{mg} / \mathrm{l}$ of 4-Chlorophenol and $85 \mathrm{mg} / \mathrm{l}$ of 4-Nitrophenol as the sole carbon and energy source respectively. Phylogenetic analysis based on $16 \mathrm{~S}$ rRNA gene sequence reveals that the strains were found to be phylogenetically close to Bacillus cereus HWB1 and Pseudomonas taiwanensis ECAe22 respectively. Optimization of physicochemical parameters was performed with Change of one variable at a time (COVT) approach. Optimized physical parameters for degradation by Bacillus cereus $H W B 1$ was found to be $30^{\circ} \mathrm{C}, \mathrm{pH} 7$ and $150 \mathrm{rpm}$ whereas for Pseudomonas tainvanensis ECAe22 it was found to be $30^{\circ} \mathrm{C}, \mathrm{pH} 8.5$ and $150 \mathrm{rpm}$. Supplementation of an additional substrate such as yeast extract was found to increase the rate of 4-Chlorophenol and 4Nitrophenol degradation owing to the increase in biomass production resulting in enhanced biodegradation. Biodegraded samples of these phenolic compounds showed negligible phytotoxicity as compared to the untreated samples thereby proving that employing these pure cultures can help in mitigating environmental contamination by phenolic compounds in the near future.
\end{abstract}

Keywords: Biodegradation, 4-Chlorophenol,4-Nitrophenol, pure cultures, $16 \mathrm{~S} r \mathrm{RN}$ A, phylogenetic analysis Abbreviation: 4-CP: 4-Chlorophenol; 4-NP: 4-Nitrophenol; AU: Absorbance Unit; MSM: Minimal Salt Media

\section{Introduction}

Phenol and its derivatives such as chlorophenols and nitrophenols are ubiquitous pollutants found in the environment which are known to be a serious matter of concern over the past few decades. They are produced as by-products from various sources such as bleaching of paper pulp, fertilizer, pesticide, coke oven industries, tannery, pharmaceuticals, textile dyes, solvents, plasticizers, etc. (Borghei \& Hosseini, 2004; Song-hu \& Xiao-hua, 2005). They are considered as priority pollutants owing to deleterious effects these pose on the biota. They are hazardous even at lower concentrations and are carcinogenic and mutagenic in nature. They are also recalcitrant and posses the capacity for bioaccumulation and therefore must be properly treated before being discharged into the environment.

Though there are various physical and chemical processes available for the treatment of phenolic wastes such as activated carbon adsorption, oxidation processes,catalytic hydrodechlorination (Díaz et al., 2008; Pera-titus, Garc, Baños, Giménez, \& Esplugas, 2004; Santos, Yustos, Quintanilla, Rodr, \& Garc, 2002) etc. but owing to their expensive and environmental polluting approach such methods are not preferred. The need of the hour gives rise to the use of biological means of treatment which deals with employing microbial cultures both as pure cultures and as communities for mitigating such toxic wastes from the environment which are not only cheap but eco-friendly as well. 
Though various pure cultures have been isolated which can degrade phenols and its various derivatives (Jamshidian, Khatami, Mogharei, Vahabzadeha, \& Nickzad, 2013; JIANG et al., 2008; Karimi \& Hassanshahian, 2015; M. Kulkarni \& Chaudhari, 2006; Nordin, 2004; Qiu, Zhong, Li, Bai, \& Li, 2007) the search for potent microbial strain continues. Our study aims to isolate bacterial cultures which possess the potential to utilize 4-Chlorophenol and 4-Nitrophenol as their sole carbon source followed by their phylogenetic and biochemical characterization and investigation of the physicochemical parameters by Change of One Variable at a Time (COVT) approach.

\section{Materials and Methods}

\subsection{Materials}

Chemicals used were of analytical and HPLC grade, were purchased from Sigma Aldrich (USA), Himedia (India), and Merck (India) .4-Nitrophenol and 4-Chlorophenol was obtained from Spectrochem Pvt. Ltd (India) and Himedia respectively The initial pH of the medium was maintained at 7.0 for 4-Chlorophenol degradation and 8 for 4Nitrophenol degradation and the working volume of the medium was $50 \mathrm{ml}$ in $250 \mathrm{ml}$ Erlenmeyer flask in all experiments. Minimal Salt Media (MSM) for 4-chlorophenol degradation consisted of $(\mathrm{g} / \mathrm{l}) \mathrm{NH}_{4} \mathrm{NO}_{3} 0.5, \mathrm{MgSO}_{4} \cdot 7 \mathrm{H}_{2} \mathrm{O} 0.2, \mathrm{~K}_{2} \mathrm{HPO}_{4} 0.5, \mathrm{KH}_{2} \mathrm{PO}_{4}$ $0.5, \mathrm{CaCl}_{2} \cdot 2 \mathrm{H}_{2} \mathrm{O}$ 0.02. The trace element solution was added to the inorganic medium at $10 \mathrm{ml} / 1$ and contained (in gram per liter) $\mathrm{FeSO}_{4} \cdot 7 \mathrm{H}_{2} \mathrm{O} 0.3, \mathrm{MnSO}_{4} \cdot \mathrm{H}_{2} \mathrm{O} 0.05$, $\mathrm{CoCl}_{2} \cdot 6 \mathrm{H}_{2} \mathrm{O} \quad 0.1, \mathrm{Na}_{2} \mathrm{MoO}_{4} \cdot 2 \mathrm{H}_{2} \mathrm{O} 0.034, \mathrm{ZnSO}_{4}$ 0.04, and $\mathrm{CuSO}_{4} \cdot 5 \mathrm{H}_{2} \mathrm{O} 0.05$ ( Basak, Bhunia, Mukherjee, \& Dey, 2014). Minimal Salt media for 4-nitrophenol degradation comprised of $(\mathrm{g} / \mathrm{l}) \mathrm{KH}_{2} \mathrm{PO}_{4} 1.2, \mathrm{~K}_{2} \mathrm{HPO}_{4} 4.8, \mathrm{MgSO}_{4} .7 \mathrm{H}_{2} \mathrm{O} \quad 0.25, \mathrm{FeSO}_{4} \cdot 7 \mathrm{H}_{2} \mathrm{O} 0.0025$, $\mathrm{CaCl}_{2} \cdot 2 \mathrm{H}_{2} \mathrm{O} 0.026$ (Zohar, Kviatkovski, \& Masaphy, 2013).4-Chlorophenol and 4Nitrophenol at required concentration served as a sole source of carbon and energy.

\subsection{Isolation and characterization of 4-Chlorophenol and 4-Nitrophenol degrading bacteria}

For the isolation of a 4-Chlorophenol and 4-Nitrophenol degrading bacterial isolates ,five milliliter of sample (wastewater effluent of a petrochemical industry, Burdwan,India for 4-Nitrophenol degrading strain isolation and textile dye industry ,Hooghly, India for 4-Chlorophenol degrading strain isolation) was added to $250 \mathrm{ml}$ Erlenmeyer flask containing $50 \mathrm{ml}$ of inorganic medium (MSM) supplemented with 2.5 $\mathrm{mg} / \mathrm{l}$ of 4-Chlorophenol and 4-Nitrophenol (in separate flasks) and incubated at $30{ }^{\circ} \mathrm{C}$ in New Brunswick Innova ${ }^{\circledR} 42$ incubator shaker at $150 \mathrm{rpm}$ for $120 \mathrm{~h}$. Degradation was evaluated by monitoring OD 279 (absorption wavelength for 4-Chlorophenol) and OD 405 (absorption wavelength for 4-Nitrophenol) after every 24 hours. When OD 279 and OD 405 were found to be decreasing with time the culture was considered as an inoculum for the next transfer and ten $\mathrm{ml}$ of the culture was centrifuged and the cell pellet was suspended in five $\mathrm{ml}$ of fresh MSM and inoculated in a fresh inorganic media containing $5.0 \mathrm{mg} / 1$ of 4-Chlorophenol and 4-Nitrophenol respectively. From then on, the culture was transferred successively to fresh inorganic media using the same growth conditions at each transfer, except that the 4-Chlorophenol and 4-Nitrophenol concentration was increased stepwise with a leap of $2.5 \mathrm{mg} / 1$ varying from 2.5 to $10 \mathrm{mg} / \mathrm{l}$. The transfer was 
repeated four times at each concentration. After acclimatization for about four months, the enriched culture obtained was duly plated on solid inorganic medium supplemented with $150 \mathrm{mg} / \mathrm{l}$ of 4-Chlorophenol and $85 \mathrm{mg} / \mathrm{l}$ of 4-Nitrophenol. Colonies that appeared were purified and each separated colony was further screened for best 4-Chlorophenol degradation and 4-Nitrophenol capability. The isolate which showed maximum degradation of $150 \mathrm{mg} / \mathrm{l}$ of 4-Chlorophenol and $85 \mathrm{mg} / 1$ of 4-Nitrophenol within 48 hours was selected for further study.

The pure cultures of isolated strains were sent to GeneI, India, for identification based on sequences of $16 \mathrm{~S}$ rRNA gene. The $16 \mathrm{~S}$ rRNA gene is highly conserved and was used for the phylogenetic analysis of bacteria. The genomic DNA was extracted and the $16 \mathrm{~S}$ rRNA gene was amplified using Taq DNA polymerase by PCR. The PCR product was sequenced using the forward and reverse primers. The sequence data were aligned and analyzed for finding the closest homologous microbes. A similarity search was carried out using Bioinformatics tools such as online BLAST program (http://www.ncbi.nlm.nih.gov/) and CLUSTAL W. A maximum likelihood phylogenetic tree was generated.The morphological examination was done by Gram staining and microscopic observation using a compound microscope.

Biochemical tests were performed using Hiassorted ${ }^{\mathrm{TM}}$ Identification Kit (Himedia, India) according to the manufacturer's instructions. The Biochemical tests included detection of urease enzyme and sugar assimilation test. The positive tests were confirmed by color changes in the identification kit.

\subsection{Characterization of metabolic versatility}

The metabolic versatility of the strains was evaluated by inoculating them separately into inorganic medium supplemented with different organic compounds as a sole source of carbon and energy. All the compounds tested (Fig.2) were sterilized by membrane filtration technique. Syringe filtration unit was used with a $0.45 \mu$ membrane filter for the filtration. The compounds selected were polar and water-soluble (such as phenol,3-chlorophenol, 4-Nitrophenol, catechol) were dissolved in distilled water to prepare a stock solution of the desired concentration and then sterilized by filtration using $0.45 \mu$ hydrophilic membrane filter. The organic compounds were supplied under a sterile condition at a concentration of $10 \mathrm{mg} / \mathrm{l}$ in $250 \mathrm{ml}$ Erlenmeyer flasks containing $50 \mathrm{ml}$ of inorganic medium. Each flask was then inoculated with a cell suspension of 0.5 AU (OD ${ }_{600}$ ). Flasks inoculated but not supplied with any organic substrate, were taken as negative control. The residual concentrations of these compounds were measured by spectrophotometric analysis after incubation of $48 \mathrm{~h}$.

\subsection{Effect of physical parameters ( $\mathrm{pH}$, temperature and agitation ) on the growth of the isolates}

To determine the optimal $\mathrm{pH}$ for the growth of the isolate, the isolated strains ( $0.1 \mathrm{AU})$ were grown in MSM broths as well as agar plates of different $\mathrm{pH}$ in the range of 5 - 11, supplemented with the substrates under study $(150 \mathrm{mg} / 1$ of 4-CP and $85 \mathrm{mg} / 1$ of 4-NP separately) and incubated for 5 days for 4-Chlorophenol (Fig.3a) and 3 days for 4Nitrophenol (Fig. 3b) degrading strains (based on previous studies) at $30^{\circ} \mathrm{C}$. The number of colonies appeared after incubation was noted and colony forming units $/ \mathrm{ml}$ 
was calculated. The residual substrate is also analyzed at the respective wavelengths.

To determine the optimal temperature for the growth of the isolates, the strains were inoculated onto MSM broths and agar plates of $\mathrm{pH} 7.0$ with added 4-Chlorophenol (Fig. 4a) and of $\mathrm{pH} 8.5$ with added 4-Nitrophenol (Fig. 4b) and incubated for 5 days at different temperatures like $28-36^{\circ} \mathrm{C}$. The number of colonies appeared after the incubation period was counted and colony forming units $/ \mathrm{ml}$ was calculated. $4 \mathrm{ml}$ of the culture was sampled out from the MSM broth after 48 hours and subjected to centrifugation at $4000 \mathrm{rpm}$ at $4^{\circ} \mathrm{C}$ for 20 minutes. The supernatant was collected and analyzed spectrophotometrically at the specific wavelength to calculate the percentage of degradation of the substrate.

The similar procedure was repeated with MSM broth in shake flasks to evaluate the effects of agitation in the range of $90-180 \mathrm{rpm}$. The 5 days old culture was duly diluted and plated to determine $\mathrm{CFU} / \mathrm{ml}$. In the above procedures counting the colony forming units gives a direct indication of the degradation of the substrates used as a growth supplement in an inorganic medium as $\mathrm{CFU} / \mathrm{ml}$ is directly proportional to the degradation (Fig. 5a \& 5b).

\subsection{Cometabolism of yeast extract and 4-Chlorophenol}

To evaluate the impact of the growth of the isolate and degradation of 4Chlorophenol by the addition of yeast extract in the media, different concentrations of yeast extract in the range of $0.1-0.3 \%$ was added to the minimal salt media. $150 \mathrm{mg} / \mathrm{l}$ of 4-Chlorophenol was tested. OD 600 (biomass) and $\mathrm{OD}_{279}$ (to evaluate 4-Chlorophenol degradation) were monitored at different time intervals (Fig.7a \& 7b).

\subsection{Cometabolism of yeast extract and 4-Nitrophenol}

In order to study the feasibility of using yeast extract as a growth substrate for 4Nitrophenol cometabolism, runs at $85 \mathrm{mg} / \mathrm{l}$ of 4-Nitrophenol concentrations were carried out with $0.1-0.3 \%$ of yeast extract as the only added co-substrate. Degradation of 4-Nitrophenol was monitored with different intervals of time spectrophotometrically at $405 \mathrm{~nm}$ (Fig. 8a \& 8b)

\subsection{Phytotoxicity tests}

To determine the effect of biodegraded and untreated pollutants such as 4Chlorophenol (Table 2) and 4-Nitrophenol (Table 3) on shoot length of a few significant seed variants were tested in $5 \mathrm{ml}$ of samples in alternate dark and light intensity at room temperature $\left(25^{\circ} \mathrm{C}\right)$. The germination was carried out in triplicates in petri dishes containing 20 seeds for each experiment (control, treated and untreated) and shoot length $(\mathrm{mm})$ was monitored every 24 hours and noted.

\section{Results}

\subsection{Isolation and characterization of the isolates}

After the composite culture was plated on MSM plates supplemented with 150 $\mathrm{mg} / \mathrm{l}$ of 4-Chlorophenol and $85 \mathrm{mg} / \mathrm{l}$ of 4-Nitrophenol (separately) and incubated for a 48 hours period at $30^{\circ} \mathrm{C}$ a number of different colonies are observed. Morphologically 
different colonies are obtained as pure cultures and separately tested for degradation of $150 \mathrm{mg} / \mathrm{l}$ of 4-Chlorophenol and $85 \mathrm{mg} / \mathrm{l}$ of 4-Nitrophenol in fresh MSM broth for 48 hours. The colonies which showed the fastest degradation rates were chosen to be the desired isolate to be studied under this experiment. The isolates obtained were subjected to gram staining. The 4-Chlorophenol degrading isolate was found to be Gram-positive and rod-shaped. .The colonies are tiny, opaque and round in shape. The 4-Nitrophenol degrading colonies were found to be gram negative and rod-shaped.

Biochemical characterization of the strains was performed using HiMedia ${ }^{\mathrm{TM}}-\mathrm{K} 001-1 \mathrm{KT}$ for evaluation of utilization of various carbon sources according to the manufacturer's instructions. Table 1 shows the result of the biochemical test. On performing the phylogenetic analysis the 4-CP (strain 1) and 4-NP degrading strains (strain 2) were found to show over 99\% sequence identity with to be Bacillus cereus HWB1 (Fig. 1a) and Pseudomonas taiwanensis ECAe22 (Fig. 1b) respectively. A maximum likelihood phylogenetic tree was generated. Fig $1 \mathrm{a}$ and Fig $1 \mathrm{~b}$ displays the phylogenetic trees of the 4-Chlorophenol and 4-Nitrophenol degrading isolates respectively.

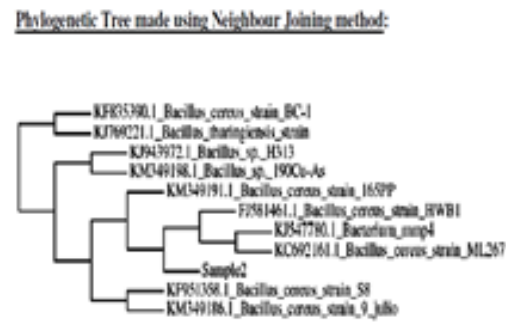

(a)

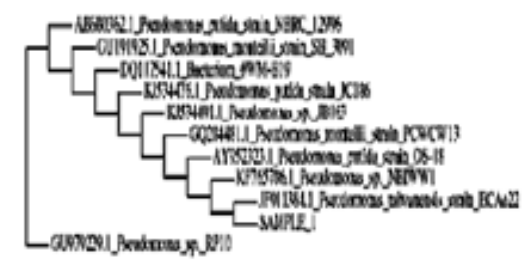

(b)

Fig 1: (a) Phylogenetic tree of the 4-Chlorophenol degrading isolate (strain 1); (b) Phylogenetic tree of the 4Nitrophenol degrading isolate (strain 2)

Table 1: Biochemical test results for strain 1 and strain 2

\begin{tabular}{lcc}
\hline Biochemical tests & $\begin{array}{c}\text { Bacillus } \\
\text { Cereus HWB1 }\end{array}$ & $\begin{array}{c}\text { Pseudomonas } \\
\text { taiwanensis ECAe22 }\end{array}$ \\
\hline Citrate utilization & + & + \\
Lysine utilization & - & - \\
Ornithine utilization & - & - \\
Urease & + & - \\
Phenylalanine deamination & - & - \\
Nitrate reduction & - & + \\
$\mathbf{H}_{2}$ S production & - & - \\
Glucose & + & + \\
Adonitol & + & + \\
Lactose & + & + \\
Arabinose & - & + \\
Sorbitol & - & - \\
\hline
\end{tabular}




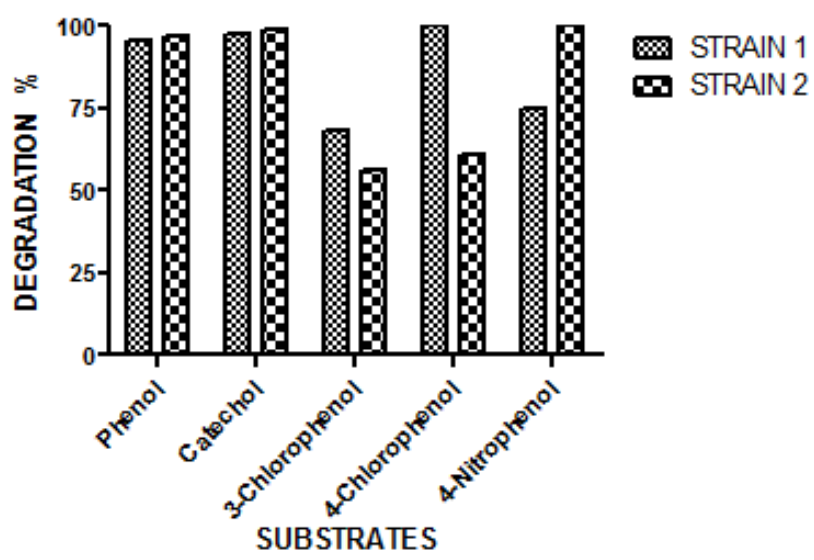

Fig 2: Metabolic versatility characterization of 4-CP degrading (strain 1) and 4-NP degrading strains (strain 2)

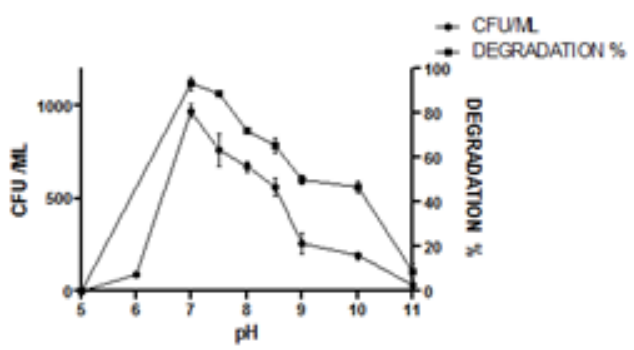

(a)

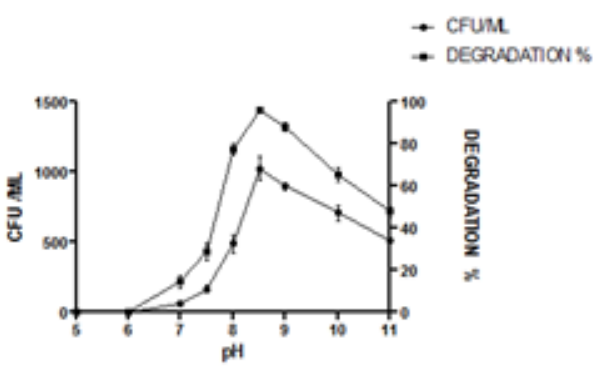

(b)

Fig 3: Effect of pH on the (a) growth and degradation of $150 \mathrm{mg} / \mathrm{l}$ of 4-Chlorophenol by strain 1 after 5 days incubation (0.1 AU) (b) growth and degradation of $85 \mathrm{mg} / \mathrm{l}$ of 4-Nitrophenol by strain 2 after 3 days incubation (0.1 AU)

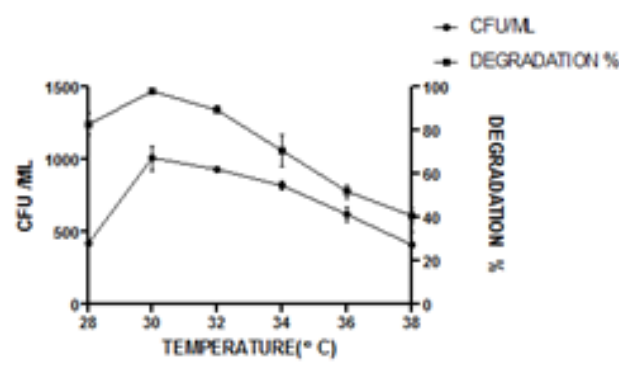

(a)

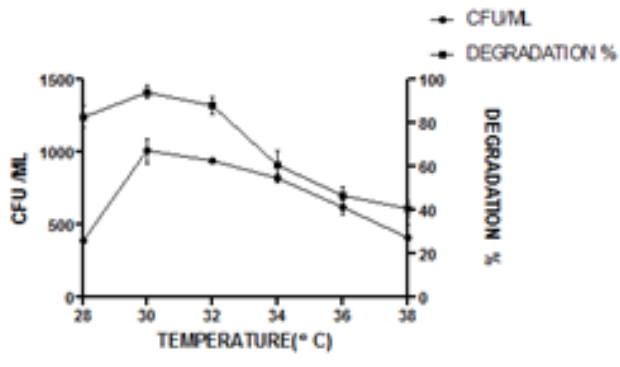

(b)

Fig 4: Effect of Temperature on the (a) growth and degradation of $150 \mathrm{mg} / \mathrm{l}$ of 4- chlorophenol by strain 1 after 5 days (b)growth and degradation of $85 \mathrm{mg} / \mathrm{l}$ of 4-Nitrophenol by strain 2 after 3 days 


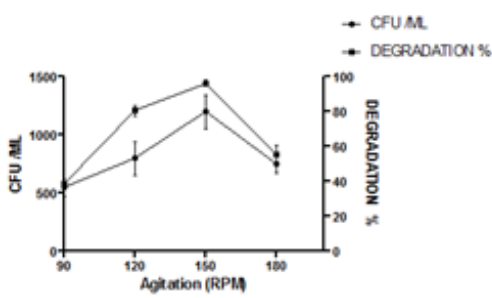

(a)

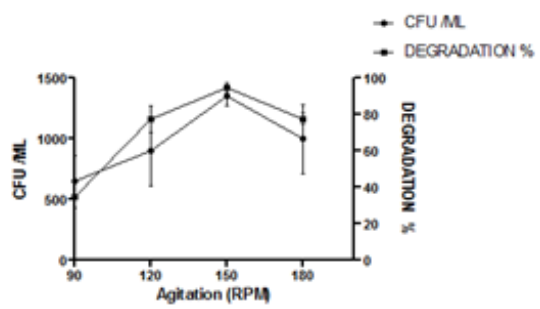

(b)

Fig. 5:(a) growth and degradation profile of strain $1 \mathrm{on} 150 \mathrm{mg} / \mathrm{l}$ of 4-CP at different agitation speed at $\mathrm{pH} 7$ and $30^{\circ} \mathrm{C}$ after 5 days (b) growth and degradation profile of strain 2 on $85 \mathrm{mg} / \mathrm{l}$ of 4-NP at different agitation speed at $\mathrm{pH} 8.5$ at $30^{\circ} \mathrm{C}$ after 3 days

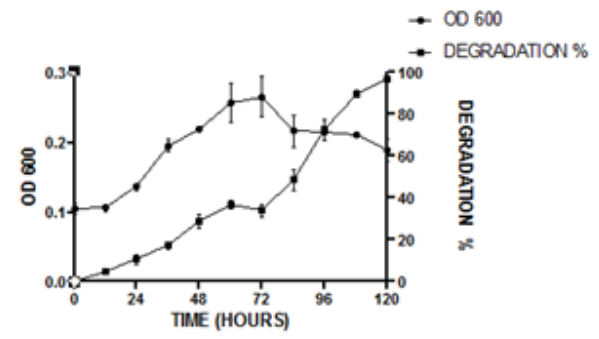

(a)

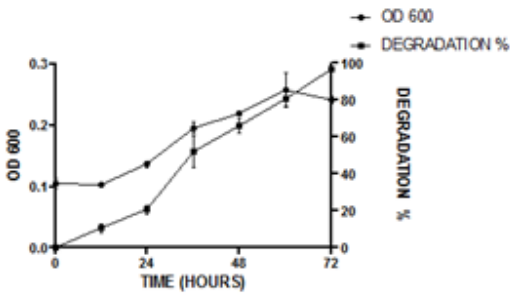

(b)

Fig 6:(a) Growth and degradation profile of strain 1 on $150 \mathrm{mg} / \mathrm{l}$ of 4-chlorophenol at $p H$ 7,30 ${ }^{\circ} \mathrm{C}, 150 \mathrm{rpm}$ (b) Growth and degradation profile of strain 2 on $85 \mathrm{mg} / \mathrm{l}$ of 4-Nitrophenol at pH 8.5,30 ${ }^{\circ} \mathrm{C}, 150 \mathrm{rpm}$

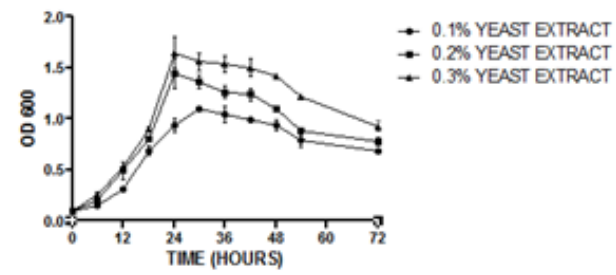

(a)

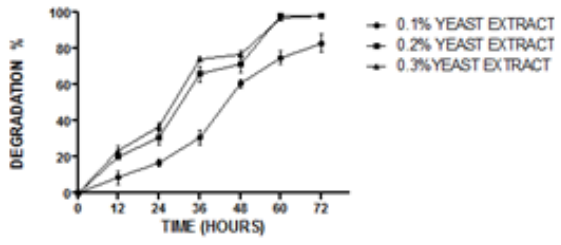

(b)

Fig 7: Effect of different concentrations of yeast extract on the (a) growth and (b) degradation of strain 1 on 150 $\mathrm{mg} / \mathrm{l}$ of 4-Chlorophenol at $30^{\circ} \mathrm{C}, 150 \mathrm{rpm}$ with $0.1 \mathrm{AU}$

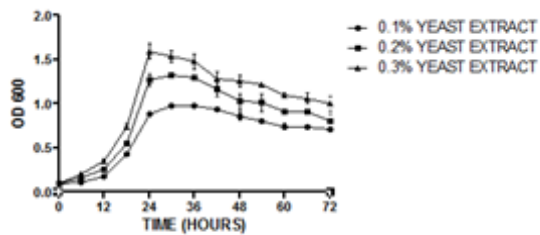

(a)

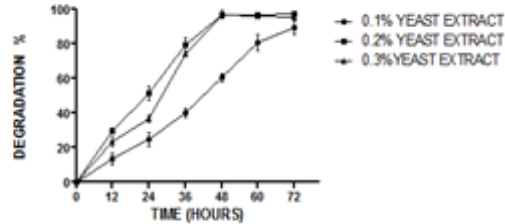

(b)

Fig 8: Effect of different concentrations of yeast extract on the (a) growth and (b) degradation of strain 2 on 85 $\mathrm{mg} / \mathrm{l}$ of 4-Nitrophenol at $30^{\circ} \mathrm{C}, 150 \mathrm{rpm}$ with $0.1 \mathrm{AU}$ 
Table 2: Phytotoxicity testing results for 4-Chlorophenol

\begin{tabular}{|c|c|c|c|c|c|c|}
\hline \multicolumn{7}{|c|}{ Growth of shoot length $(\mathrm{mm})$} \\
\hline & & $1^{\text {st }}$ day & $2^{\text {nd }}$ day & $3^{\text {rd }}$ day & $4^{\text {th }}$ day & $5^{\text {th }}$ day \\
\hline \multirow{3}{*}{$\begin{array}{l}\text { Gram seeds } \\
\text { (Cicer arietinum) }\end{array}$} & Control & 5 & 11 & 20 & 27 & 36 \\
\hline & Untreated & 2 & 2.6 & 5 & 9 & 13 \\
\hline & Treated & 3 & 10 & 14 & 21 & 28 \\
\hline \multirow{3}{*}{$\begin{array}{l}\text { Pea seeds } \\
\text { (Pisum sativum) }\end{array}$} & Control & 10 & 19 & 29 & 45 & 78 \\
\hline & Untreated & 0 & 5 & 7 & 17 & 27 \\
\hline & Treated & 3 & 9 & 16 & 22 & 31 \\
\hline \multirow{3}{*}{$\begin{array}{l}\text { Mustard seeds } \\
\text { (Brassica juncea) }\end{array}$} & Control & 5 & 10 & 22 & 34 & 48 \\
\hline & Untreated & No growth & Growth starts & 1 & 3 & 4 \\
\hline & Treated & 8 & 14 & 25 & 33 & 42 \\
\hline \multirow{3}{*}{$\begin{array}{l}\text { Mung seeds } \\
\text { (Vigna radiata) }\end{array}$} & Control & 8 & 24 & 32 & 62 & 86 \\
\hline & Untreated & 3 & 6 & 17 & Turned black & Turned black \\
\hline & Treated & 9 & 18 & 28 & 58 & 72 \\
\hline \multirow{3}{*}{$\begin{array}{l}\text { Coriander } \\
\text { (Coriandrum sativum) }\end{array}$} & Control & 15 & 34 & 56 & 71 & 96 \\
\hline & Untreated & No growth & No growth & 2 & 7 & 12 \\
\hline & Treated & \begin{tabular}{|l|} 
No growth \\
\end{tabular} & No growth & Growth starts & 3 & 5 \\
\hline
\end{tabular}

Control: Seeds supplemented with only water

Untreated: Seeds supplemented with $10 \mathrm{mg} / \mathrm{l}$ of 4-Chlorophenol

Treated: Seeds supplemented with biodegraded sample of $10 \mathrm{mg} / \mathrm{l}$ of 4-Chlorophenol

Table 3: Phytotoxicity testing results for 4-Nitrophenol

\begin{tabular}{|c|c|c|c|c|c|c|}
\hline \multicolumn{7}{|c|}{ Growth of shoot length (mm) } \\
\hline & & $1^{\text {st }}$ day & $2^{\text {nd }}$ day & $3^{\text {rd }}$ day & $4^{\text {th }}$ day & $5^{\text {th }}$ day \\
\hline \multirow{3}{*}{ Gram seeds (Cicer arietinum) } & Control & 9 & 18 & 31 & 51 & 75 \\
\hline & Untreated & 2 & 5 & 12 & 17 & 23 \\
\hline & Treated & 4 & 23 & 30 & 38 & 45 \\
\hline \multirow{3}{*}{$\begin{array}{l}\text { Pea seeds } \\
\text { (Pisum sativum) }\end{array}$} & Control & 8 & 17 & 40 & 68 & 90 \\
\hline & Untreated & 1 & 8 & 20 & 26 & 31 \\
\hline & Treated & 4 & 21 & 36 & 47 & 59 \\
\hline \multirow{3}{*}{$\begin{array}{l}\text { Mustard seeds } \\
\text { (Brassica juncea) }\end{array}$} & Control & 5 & 9 & 19 & 24 & 29 \\
\hline & Untreated & No growth & No growth & 2 & 3 & 5 \\
\hline & Treated & 2 & 7 & 17 & 20 & 23 \\
\hline \multirow{3}{*}{$\begin{array}{l}\text { Mung seeds } \\
\text { (Vigna radiate) }\end{array}$} & Control & 15 & 22 & 42 & 71 & 92 \\
\hline & Untreated & 5 & 10 & 21 & 24 & Turned black \\
\hline & Treated & 12 & 17 & 29 & 35 & 48 \\
\hline \multirow{3}{*}{$\begin{array}{l}\text { Coriander } \\
\text { (Coriandrum sativum) }\end{array}$} & Control & 11 & 21 & 36 & 51 & 76 \\
\hline & Untreated & No growth & No growth & No growth & No growth & No growth \\
\hline & Treated & No growth & No growth & Growth starts & 3 & 7 \\
\hline
\end{tabular}

Control: Seeds supplemented with only water

Untreated: Seeds supplemented with $10 \mathrm{mg} / \mathrm{l}$ of 4-Nitrophenol

Treated: Seeds supplemented with biodegraded sample of $10 \mathrm{mg} / \mathrm{l}$ of 4-Nitrophenol

\subsection{Metabolic versatility characterization of the isolated strains}

Strain 1 was found to be more metabolically versatile than the strain 2 as the former degraded more than $95 \%$ of $10 \mathrm{mg} / \mathrm{l}$ of phenol and catechol ,100\% of 4Chlorophenol ,78\% of 4-Nitrophenol and about $68 \%$ of 3 -chlorophenol whereas strain 2 was found to degrade more than $96 \%$ of phenol and catechol, about $50 \%$ of 3chlorophenol, 61\% of 4-Chlorophenol and 100\% of 4-Nitrophenol (Fig 2). This indicates that a higher percentage of phenol and catechol are degraded by the isolates in 
comparison with that of other substrates because of their simpler structures whereas the presence of chloro and nitro substituents make the other substrates difficult to degraded thereby making them recalcitrant.

\subsection{Effect of physical parameters $(\mathrm{pH}$, temperature and agitation ) on the growth of the isolates}

$\mathrm{pH}$, temperature, and agitation are important physical parameters which have a crucial impact on the biodegradation of the pollutants by affecting the growth of the microorganism involved in the process. For both the isolates, $30^{\circ} \mathrm{C}$ was found to be the optimum temperature for biodegradation of the substrates under study with more than $97 \%$ of 4 -Chlorophenol and approximately $96 \%$ of 4 -Nitrophenol being degraded by the respective isolates within 5 days and 3 days of incubation respectively under $30^{\circ} \mathrm{C}$ (Fig.4). According to most of the reports, the optimum temperature for biodegradation lies in the range of $25-35^{\circ} \mathrm{C}$. Basak, Bhunia, Dutta, \& Dey, 2013 found that increasing the temperature from $28^{\circ} \mathrm{C}$ to $30^{\circ} \mathrm{C}$ resulted in an improved rate of biodegradation of 4Chlorophenol by a yeast Candida tropicalis PHB5 which can be attributed to the improved growth of the biomass thereby leading to increased degradation of 4-CP. PNP degradation efficiency is found to be optimal at temperature $30^{\circ} \mathrm{C}$ (Leilei, Mingxin, \& Suiyi, 2012). Qiu, Wu, Zhang, Li, \& Yan, 2009 in their study with the degradation of 4Nitrophenol by Arthrobacter sp. HY2 showed that the maximum degradation occurs at $30^{\circ} \mathrm{C}$. Temperature is one of the significant factors which plays an important role in influencing the growth and the enzymatic activity of the microbial cells. At the optimum temperature, there is maximal growth and enzyme activity leading to the increased degradation rate. Decreasing and increasing the temperature beyond the optimum point hinders the growth of the cells thereby reducing the biodegradation process. Qiu et al., 2009 claim enhanced degradation of 4-Nitrophenol at elevated $\mathrm{pH}$ owing to the increased bioavailability and reduced toxicity of 4-NP and optimum metabolic activity of the microbial cells involved in the degradation process (Wan, Gu,\& Yan, 2007).Very high and low $\mathrm{pH}$ results in loss of enzyme activity that is involved in the biochemical processes thus affecting the rate of biodegradation.

Agitation is also an important process parameter which influences biodegradation. Both the strains showed maximum degradation at $150 \mathrm{rpm}$ (Fig.5) which can be attributed to the fact that agitation affects the oxygen mass transfer rate (Shuler \& Kargi, 2002). Agitation in the range of $120-160 \mathrm{rpm}$ results in higher dissolved oxygen concentration which positively affects the biodegradation of 4-Chlorophenol and 4-Nitrophenol by the isolated microbial strains as biodegradation of such substrates follows an aerobic process. Several other researchers have also documented similar effects of agitation (Kaushik \& Thakur, 2009).

\subsection{Effect of yeast extract on the cometabolism of 4-Chlorophenol and 4- Nitrophenol}

In the cometabolic transformation of 4-Chlorophenol and 4-Nitrophenol (Fig.7 \& Fig.8), yeast extract serves as a good co-substrate. It was found that with increasing yeast extract concentrations $(0.1-0.3 \%)$ there was enhanced biodegradation of both the pollutants. The lag phase was reduced and the time for degradation was decreased. This 
can be attributed to the fact that yeast extract serves as a nitrogen source and is used for the synthesis of cellular components (N. Kulkarni, Shendye, \& Rao, 1999; Suvarna, Subba, Sreenivas, Hobbs, \& Shetty, 2009) and thereby leading to the biomass proliferation which in turn leads to faster biodegradation. However, increasing the yeast extract percentage beyond $0.2 \%$ did not have any significant effect on the rate of biodegradation of both 4-Chlorophenol and 4-Nitrophenol even if there was a slight increase in the biomass production as compared to when the media was supplemented with $0.2 \%$ yeast extract.

\subsection{Phytotoxicity tests}

Control sets show the best growth in length for all the five seed variants under study. In the presence of the treated sample, the shoot growth is comparatively lower than the control while the untreated samples showed the least growth which was indicative of the toxicity posed on the seeds by the pollutants (Table $2 \& 3$ ). The growth of shoots in presence of treated samples throws light on the efficacy of the isolated bacterial strains in degrading the pollutants under study (4-Chlorophenol and 4-Nitrophenol) thereby making it feasible for the seeds to germinate. However, Coriander and mustard show less growth as compared to the other seed variants which reveal that they are more sensitive than the others and lack pollutant tolerant potential, unlike other seeds.

\section{Conclusion}

The present study is aimed at isolation and characterization of pure cultures followed by optimization of physicochemical parameters using COVT approach for the degradation of 4-Chlorophenol and 4-Nitrophenol. The isolated microbial strains bearing 99\% resemblance with Bacillus cereus HWB1 and Pseudomonas taiwanensis ECAe22 are able to degrade up to $98.73 \%$ of $150 \mathrm{mg} / \mathrm{l}$ of 4-Chlorophenol and $96.81 \%$ of $85 \mathrm{mg} / \mathrm{l}$ of 4Nitrophenol within 5 days and 3 days respectively as the sole source of carbon and energy. The strains are found to be metabolically versatile as they are able to grow on a few other aromatic compounds as well such as phenol, catechol, 3-chlorophenol, and 4-Nitrophenol. This finding is of significance because of the fact that industrial wastewaters are often a mixture of various toxic phenolic compounds and thus these isolates can of importance in treating such effluents. Yeast extract has a positive impact on the biodegradation of 4Chlorophenol and 4-Nitrophenol. Cosubstrates such as yeast extract attenuate the toxicity of hazardous substrates and results in an increase in biodegradation efficiency and removal rate owing to the increase in biomass due to consumption of primary substrates. Phytotoxicity test of the samples on different seed variants indicated that the toxicity of the pollutants was sufficiently reduced after biodegradation by the isolated microorganisms thereby resulting in shoot growth, unlike untreated samples.

\section{Acknowledgment}

The authors thank the Department of Biotechnology (DBT), Government of India, for their financial aid and National Institute of Technology Durgapur for technical support.

\section{References}


Basak, B., Bhunia, B., Dutta, S., \& Dey, A. (2013). International Biodeterioration \& Biodegradation Enhanced biodegradation of 4-chlorophenol by Candida tropicalis PHB5 via optimization of physicochemical parameters using Taguchi orthogonal array approach. International Biodeterioration \& Biodegradation, 78, 17-23. https://doi.org/10.1016/j.ibiod.2012.12.005

Borghei, S. M., \& Hosseini, S. H. (2004). The treatment of phenolic wastewater using a moving bed biofilm reactor, 39, 1177-1181. https://doi.org/10.1016/S0032-9592(02)00195-4

Díaz, E., Casas, J. A., Mohedano, Á. F., Calvo, L., Gilarranz, M. A., \& Rodríguez, J. J. (2008). Kinetics of the Hydrodechlorination of 4-Chlorophenol in Water Using Pd, Pt, and Rh / Al 2 O 3 Catalysts, 3840-3846.

Jamshidian, H., Khatami, S., Mogharei, A., Vahabzadeha, F., \& Nickzad, A. (2013). Cometabolic degradation of para-nitrophenol and phenol by Ralstonia eutropha in a Kissiris-immobilized cell bioreactor. Korean Journal of Chemical Engineering, 30(11), 2052-2058. https://doi.org/10.1007/s11814-013-0145-1

JIANG, Y., REN, N., CAI, X., WU, D., QIAO, L., \& LIN, S. (2008). Biodegradation of Phenol and 4Chlorophenol by the Mutant Strain CTM 2. Chinese Journal of Chemical Engineering. https://doi.org/10.1016/S1004-9541(08)60158-5

Karimi, M., \& Hassanshahian, M. (2015). Isolation and characterization of phenol degrading yeasts from wastewater in the coking plant of Zarand, Kerman. Brazilian Journal of Microbiology, 47(1), 18-24. https://doi.org/10.1016/j.bjm.2015.11.032

Kaushik, G., \& Thakur, I. S. (2009). International Biodeterioration \& Biodegradation Isolation and characterization of distillery spent wash color reducing bacteria and process optimization by Taguchi approach. International Biodeterioration \& Biodegradation, 63(4), 420-426. https://doi.org/10.1016/j.ibiod.2008.11.007

Kulkarni, M., \& Chaudhari, A. (2006). Biodegradation of $\mathrm{p}$-nitrophenol by P . putida, 97, 982-988. https://doi.org/10.1016/j.biortech.2005.04.036

Kulkarni, N., Shendye, A., \& Rao, M. (1999). Molecular and biotechnological aspects of xylanases, 23(February).

Leilei, Z., Mingxin, H., \& Suiyi, Z. (2012). Biodegradation of p -nitrophenol by Immobilized Rhodococcus sp . Strain Y-1, 26(2), 137-144.

Nordin, K. (2004). 4-chlorophenol biodegradation by Artbrobacter chlorophenolicus A6.

Pera-titus, M., Garc, V., Baños, M. A., Giménez, J., \& Esplugas, S. (2004). Degradation of chlorophenols by means of advanced oxidation processes: a general review, 47, 219-256. https://doi.org/10.1016/j.apcatb.2003.09.010

Qiu, X., Wu, P., Zhang, H., Li, M., \& Yan, Z. (2009). Bioresource Technology Isolation and characterization of Arthrobacter sp. HY2 capable of degrading a high concentration of $\mathrm{p}$-nitrophenol. Bioresource Technology, 100(21), 5243-5248. https://doi.org/10.1016/j.biortech.2009.05.056

Qiu, X., Zhong, Q., Li, M., Bai, W., \& Li, B. (2007). Biodegradation of p-nitrophenol by methyl parathiondegrading Ochrobactrum sp. B2. International Biodeterioration and Biodegradation, 59(4), 297-301. https://doi.org/10.1016/j.ibiod.2006.09.005

Santos, A., Yustos, P., Quintanilla, A., Rodr, S., \& Garc, F. (2002). Route of the catalytic oxidation of phenol in aqueous phase, 39, 97-113.

Song-hu, Y., \& Xiao-hua, L. (2005). Comparison treatment of various chlorophenols by electro-Fenton method: relationship between chlorine content and degradation, 118, 85-92. https://doi.org/10.1016/j.jhazmat.2004.08.025

Suvarna, G., Subba, C., Sreenivas, R., Hobbs, P. J., \& Shetty, R. (2009). Enhanced production of xylanase by a newly isolated Aspergillus terreus under solid state fermentation using palm industrial waste : A statistical optimization, 48, 51-57. https://doi.org/10.1016/j.bej.2009.08.005

Basak, B., Bhunia, B., Mukherjee, S., \& Dey, A. (2014). Desalination and Water Treatment Optimization of physicochemical parameters for phenol biodegradation by Candida tropicalis PHB5 using Taguchi Methodology, 37-41. https://doi.org/10.1080/19443994.2013.770638

Wan, N., Gu, J., \& Yan, Y. (2007). Degradation of p -nitrophenol by Achromobacter xylosoxidans Ns isolated from wetland sediment, 59, 90-96. https://doi.org/10.1016/j.ibiod.2006.07.012

Zohar, S., Kviatkovski, I., \& Masaphy, S. (2013). Increasing tolerance to and degradation of high p-nitrophenol concentrations by inoculum size manipulations of Arthrobacter $4 \mathrm{H} \beta$ isolated from agricultural soil. International Biodeterioration and Biodegradation, 84, 80-85. https://doi.org/10.1016/j.ibiod.2012.05.041 